\title{
Socio-demographic and economic factors influencing utilization of youth friendly reproductive health services among youths in selected universities in Nairobi County, Kenya
}

\author{
Felix Mwendwa Mutua ${ }^{1 *}$, Jane Karonjo ${ }^{2}$, Jackline Mosinya Nyaberi ${ }^{3}$, \\ Peter Kamau $^{4}$, John Kausya ${ }^{1}$, Faith Mugai ${ }^{1}$
}

\begin{abstract}
${ }^{1}$ Department of Epidemiology and Biostatistics, ${ }^{2}$ School of Nursing, Mount Kenya University (MKU), Nairobi, Kenya
${ }^{3}$ School of Public Health, Jomo Kenyatta University of Agriculture and Technology, Juja, Kenya

${ }^{4}$ Department of Community Health, Kenyatta University, Nairobi, Kenya
\end{abstract}

Received: 23 January 2020

Revised: 04 March 2020

Accepted: 05 March 2020

*Correspondence:

Mr. Felix Mwendwa Mutua,

E-mail: mutuafe13@gmail.com

Copyright: (C) the author(s), publisher and licensee Medip Academy. This is an open-access article distributed under the terms of the Creative Commons Attribution Non-Commercial License, which permits unrestricted non-commercial use, distribution, and reproduction in any medium, provided the original work is properly cited.

\section{ABSTRACT}

Background: The reproductive and sexual health of the youth remains a relatively new and sensitive area mainly due to restrictive norms and policies guiding the services and also the access and utilization of youth friendly reproductive health services (YFRHS) among the college youth are dependent on many factors.

Methods: Descriptive cross-sectional design was used to study 421 youths in selected universities in Nairobi County. Systematic sampling technique was used. Data was collected using a researcher-administered structured questionnaire and Key Informant Interview. Quantitative data analysis was conducted using SPSS version 24.0 and involved univariate and bivariate analysis. Chi-square were used to test the significance of the association between the dependent and independent variables $(\mathrm{p}<0.05)$. Qualitative data was analyzed by thematic content analysis.

Results: The results indicated that $67.9 \%$ of youths utilized counselling services, $42.0 \%$ utilized VCT, $24.7 \%$ utilized family planning and $12.6 \%$ reported having used antenatal or pregnancy services. Utilization for all the reproductive health services increased with age with gender greatly associated with utilization of ANC services $(\mathrm{p}=0.0001)$, FP services $(\mathrm{p}=0.001)$ and STDs treatment $(\mathrm{p}=0.002)$ while age of an individual was associated with VCT services $(\mathrm{p}=0.0001)$, FP services $(\mathrm{p}=0.008)$ and counselling $(\mathrm{p}=0.007)$.

Conclusions: Socio-demographic factors influence utilization of YFRHS and therefore there is a need for the Government through the Ministry of Health and partners in health service provision to increase the number of YFRHS and ensure that the recommendations of Adolescent Health Policy guidelines are implemented fully with good evaluation strategies in place.

Keywords: Sexual and reproductive health, Youths, Youth friendly health services

\section{INTRODUCTION}

According to the World Health Organization (WHO), youth between 15 and 24 years and are characterized by unique physical, psychological, social, and emotional changes that put their life at high risk. ${ }^{1}$ Poor health quality impacts negatively on educational access, retention and achievement of young people in the country. Of particular concern is the access of youths to appropriate sexual and reproductive health (SRH) services. $^{2}$ Youth-friendly health services (YFHS) that are offered should be based on an understanding of what young people in a given community want and need, and 
must have respect for the realities of young people's diverse backgrounds. ${ }^{3}$

In Kenya, youth form majority of the Kenyan population; the youthful has range of many problems from social, economic and health challenges therefore their health needs ought to be addressed. ${ }^{4}$ Statistics from Kenya National Bureau of Statistics (KNBS) census report estimate the youth to be about $40 \%$ of the population and youth aged 10-24 years make up to $36 \%$ of the population..$^{5}$ According to the Ministry of Health $(\mathrm{MoH})$ cited in the Kenya Demographic and Health Survey (KDHS) 2014 report, about $56 \%$ of women and $66 \%$ of men have some level of knowledge and understanding on sexual and reproductive health with utilization rate of $63 \%$. Ministry of Health in Kenya formally approved the country's first National Reproductive Health Policy (NRHP) was formally approved by the Kenya's Ministry of Health to provide a framework for equitable, efficient and effective delivery of quality reproductive health services to the population especially those considered vulnerable such as the youth. ${ }^{6}$ The aim of the policy was to guide planning, standardization, implementation, and monitoring and evaluation of reproductive health care provided by various stakeholders. It focuses on: safe motherhood, maternal and neonatal health, family planning, and adolescent/youth sexual and reproductive health and gender issues.

The WHO estimated that $70 \%$ of premature deaths among adults are largely due to behaviours initiated during adolescences which implies that many of the healthrelated behaviours and conditions that arise during adolescence have implications for both present and future health development. ${ }^{1}$ Some of these behaviours include lack of physical activities, unhealthy diets, drug and substance use, unsafe/risky sexual behaviours, etc. and conditions such as nutrition deficiencies, injuries (intended and unintended) etc. leads to the major causes of morbidity and mortality now and the future. ${ }^{7}$ The existing health care system was general for all groups of people and was wanting in the capacity to respond to the youth. ${ }^{8}$ Although the Kenyan government adopted Adolescent Reproductive Health and Development Policy (ARH and D) in 2003 with a commitment to address adolescent reproductive health issues, there has been limited utilization of the services by the college youths. The concern about adolescent sexual and reproductive health (ASRH) has grown following reports that sexual activity, early pregnancies, drug abuse and sexually transmitted infections (STIs) including HIV infection rates are increasing at unprecedented rates among the youths. ${ }^{9}$

The access to and utilization of YFRHS is a primary concern surrounding the promotion of sexual and reproductive health and rights and there is scanty information concerning any study on utilization of reproductive health services done in Nairobi County focusing on college youth. Many adolescents die prematurely and unnecessarily through accidents, suicide, violence and pregnancy-related complications and some of the serious conditions of adulthood. In Nairobi county, there are several health facilities offering youth-friendly services and therefore its necessary to assess the utilization of YFRHS among the colleges within the county.

\section{METHODS}

This was a descriptive cross-sectional design using both quantitative methods (issuing self-administered questionnaires to the students) and qualitative methods (use of key informant interviews) of data collection from December 2018 to April 2019.

\section{Inclusion criteria}

The study included all university youths in selected universities between eighteen to twenty-four years and healthcare providers as key informants.

\section{Exclusion criteria}

Unconsented students were excluded. The students who were on suspension and those declined to give a written consent were excluded from the study.

The study utilized systematic random sampling method among 421 students from University of Nairobi (KNH Campus), Aga Khan Teaching and Referral University, United States International University and Daystar University-Nairobi campus in Nairobi County. Interviewer-administered structured questionnaires were used to collect quantitative data while Key Informant Guide was used to collect qualitative. Key informant interview respondents consisted of twelve (12) key informants including eight (8) facility-based health service providers such as health workers and health administrative staff and four (4) community-based persons (Public Health Officers). Quantitative data was analyzed using SPSS version 24.0. Descriptive data was presented using frequencies, percentages, means and standard deviation while inferential statistics used chisquare test to measure association between independent and dependent variables. P-value less than 0.05 were considered statistically significant.

\section{RESULTS}

\section{Socio-demographic Characteristics of study respondents}

In this study more than half $(58.0 \%)$ of the youth were aged 23-24 years and 11.2\% were 19-20 years. Most of the students were females $(53.2 \%)$ and $46.8 \%$ were males. The study covered youth in first year $(20.4 \%)$, second year $(49.9 \%)$, third year $(20.0 \%)$ and fourth year $(9.7 \%)$ students. Of the youth studied, $77.4 \%$ were Christians, $22.6 \%$ were Muslims and $24.2 \%$ were married (Table 1). 
Table 1: Socio-demographic characteristics of study respondents.

\begin{tabular}{|c|c|c|c|}
\hline \multicolumn{2}{|c|}{ Characteristic } & Frequency & $\%$ \\
\hline \multirow{3}{*}{$\begin{array}{l}\text { Age group } \\
\text { (in years) }\end{array}$} & $19-20$ & 47 & 11.2 \\
\hline & $21-22$ & 130 & 30.9 \\
\hline & $23-24$ & 244 & 58.0 \\
\hline \multirow{4}{*}{ University } & UON-KNH & 141 & 33.5 \\
\hline & AKUH & 66 & 15.7 \\
\hline & USIU & 94 & 22.3 \\
\hline & Daystar University & 120 & 28.5 \\
\hline \multirow{2}{*}{ Gender } & Female & 224 & 53.2 \\
\hline & Male & 197 & 46.8 \\
\hline \multirow{4}{*}{$\begin{array}{l}\text { Year of } \\
\text { study }\end{array}$} & First year & 86 & 20.4 \\
\hline & Second year & 210 & 49.9 \\
\hline & Third year & 84 & 20.0 \\
\hline & Fourth year & 41 & 9.7 \\
\hline \multirow{2}{*}{$\begin{array}{l}\text { Religion } \\
\text { affiliation }\end{array}$} & Christian & 326 & 77.4 \\
\hline & Muslim & 95 & 22.6 \\
\hline \multirow{2}{*}{$\begin{array}{l}\text { Marital } \\
\text { status }\end{array}$} & Single & 319 & 75.8 \\
\hline & Married & 102 & 24.2 \\
\hline
\end{tabular}

\section{Socio-economic characteristics of study respondents}

More than half of respondents $213(50.6 \%)$ had a source of income and $177(42.0 \%)$ of guardians were selfemployed (Table 2).

Table 2: Socio-economic characteristics of respondents.

\begin{tabular}{|llll|}
\hline \multirow{2}{*}{$\begin{array}{l}\text { Characteristics } \\
\text { Had source } \\
\text { of income }\end{array}$} & Yes & Frequency & $\%$ \\
\cline { 2 - 4 } & No & 213 & 50.6 \\
\hline \multirow{2}{*}{$\begin{array}{l}\text { Guardian } \\
\text { employmen } \\
\text { status }\end{array}$} & Farmer & 19 & 49.4 \\
\cline { 2 - 4 } & Self employed & 177 & 4.5 \\
\cline { 2 - 4 } & Casual laborer & 82 & 42.0 \\
\cline { 2 - 4 } & Formal employment & 143 & 34.0 \\
\hline
\end{tabular}

\section{Youth friendly reproductive health services utilized}

The results indicate that $67.9 \%$ of youth utilized counselling services, $42.0 \%$ utilized VCT, $24.7 \%$ utilized family planning and $12.6 \%$ reported having used antenatal or pregnancy services as shown in Figure 1.

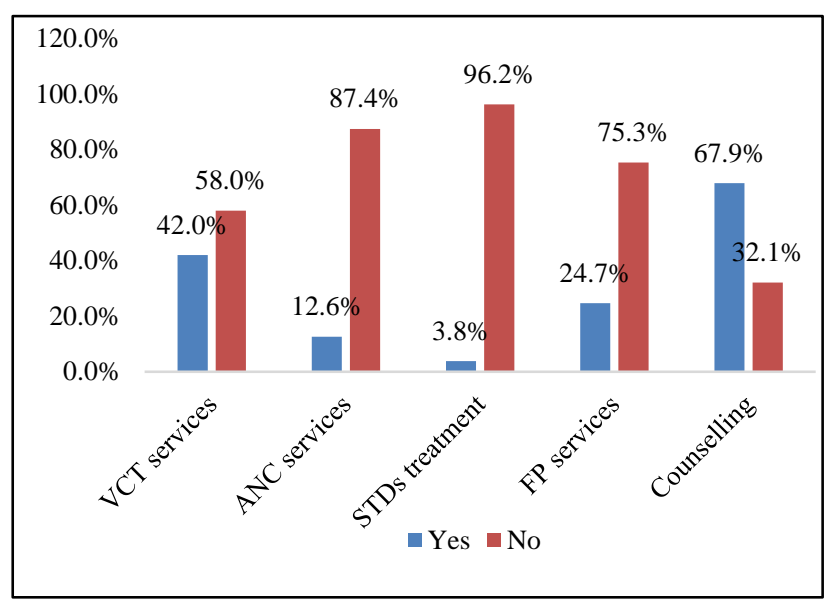

Figure 1: Youth friendly reproductive health services utilized.

\section{Socio-demographic factors that influence YFRHS utilization}

Various socio-demographic variables were subjected to Chi-square analysis test to determine association with utilization of YFRHS. The age had significant association to utilization of VCT $\left(\chi^{2}=22.921, \mathrm{df}=2, \mathrm{p}=0.001\right)$, FP services $\left(\chi^{2}=9.547 ; \quad \mathrm{df}=2 ; \quad \mathrm{p}=0.008\right)$ and general counselling $\left(\chi^{2}=9.821 ; \mathrm{df}=2 ; \mathrm{p}=0.007\right)$. Gender had significant association to utilization of ANC services $\left(\chi^{2}=\right.$ 45.071; df 1; $\mathrm{p}=0.0001)$, FP services $\left(\chi^{2}=65.242 ;\right.$ df 1 ; $\mathrm{p}=0.001)$ and STDs treatment $\left(\chi^{2}=11.069 ;\right.$ df $\left.1 ; \mathrm{p}=0.002\right)$ (Table 3).

Table 3: Socio-demographic factors and utilization of YFRHS.

\begin{tabular}{|c|c|c|c|c|c|c|}
\hline \multirow{2}{*}{ Characteristics } & & \multicolumn{2}{|c|}{ Utilized } & \multicolumn{2}{|c|}{ Not-utilized } & \multirow{2}{*}{ Statistics } \\
\hline & & $\mathbf{N}$ & $\%$ & $\mathbf{N}$ & $\%$ & \\
\hline \multicolumn{7}{|l|}{ VCT services } \\
\hline \multirow{2}{*}{ Gender } & Female & 85 & 48.0 & 139 & 57.0 & \multirow{2}{*}{$x^{2}=3.297 ; d f=1 ; p=0.075$} \\
\hline & Male & 92 & 52.0 & 105 & 43.0 & \\
\hline \multirow{3}{*}{$\begin{array}{l}\text { Age group } \\
\text { (in years) }\end{array}$} & $19-20$ & 6 & 3.4 & 41 & 16.8 & \multirow{3}{*}{$x^{2}=22.921 ; d f=2 ; p=0.0001$} \\
\hline & $21-22$ & 50 & 28.2 & 80 & 32.8 & \\
\hline & $23-24$ & 121 & 68.4 & 123 & 50.4 & \\
\hline \multirow{3}{*}{$\begin{array}{l}\text { Religion allow } \\
\text { YFRHS }\end{array}$} & Yes & 134 & 75.7 & 191 & 78.3 & \multirow{3}{*}{$x^{2}=0.633 ; d f=2 ; p=0.729$} \\
\hline & No & 5 & 2.8 & 8 & 3.3 & \\
\hline & Not sure & 38 & 21.5 & 45 & 18.4 & \\
\hline \multicolumn{7}{|l|}{ ANC services } \\
\hline \multirow{2}{*}{ Gender } & Female & 51 & 100.0 & 173 & 47.0 & \multirow{2}{*}{$x^{2}=45.071 ; d f=1 ; p=0.0001$} \\
\hline & Male & 0 & 0.0 & 197 & 53.0 & \\
\hline \multirow{3}{*}{$\begin{array}{l}\text { Age group } \\
\text { (in years) }\end{array}$} & $19-20$ & 1 & 1.9 & 46 & 12.5 & \multirow{3}{*}{$x^{2}=5.723 ; d f=2 ; p=0.057$} \\
\hline & $21-22$ & 16 & 30.2 & 114 & 31.0 & \\
\hline & $23-24$ & 36 & 67.9 & 208 & 56.5 & \\
\hline
\end{tabular}




\begin{tabular}{|c|c|c|c|c|c|c|}
\hline \multirow{2}{*}{ Characteristics } & & \multicolumn{2}{|c|}{ Utilized } & \multicolumn{2}{|c|}{ Not-utilized } & \multirow{2}{*}{ Statistics } \\
\hline & & $\mathbf{N}$ & $\%$ & $\mathbf{N}$ & $\%$ & \\
\hline \multirow{3}{*}{$\begin{array}{l}\text { Religion allow } \\
\text { YFRHS }\end{array}$} & Yes & 44 & 83.0 & 281 & 76.4 & \multirow{3}{*}{$x^{2}=1.206 ; d f=2 ; p=0.547$} \\
\hline & No & 1 & 1.9 & 12 & 3.3 & \\
\hline & Not sure & 8 & 15.1 & 75 & 20.4 & \\
\hline \multicolumn{7}{|l|}{ FP services } \\
\hline \multirow{2}{*}{ Gender } & Female & 91 & 87.5 & 133 & 42.0 & \multirow{2}{*}{$x^{2}=65.242 ; d f=1 ; p=0.001$} \\
\hline & Male & 13 & 12.5 & 184 & 58.0 & \\
\hline \multirow{3}{*}{$\begin{array}{l}\text { Age group } \\
\text { (in years) }\end{array}$} & $19-20$ & 3 & 2.9 & 44 & 13.9 & \multirow{3}{*}{$x^{2}=9.547 ; \mathrm{df}=2 ; \mathrm{p}=0.008$} \\
\hline & $21-22$ & 35 & 33.7 & 95 & 30.0 & \\
\hline & $23-24$ & 66 & 63.5 & 178 & 56.2 & \\
\hline \multirow{3}{*}{$\begin{array}{l}\text { Religion allow } \\
\text { YFRHS }\end{array}$} & Yes & 80 & 76.9 & 245 & 77.3 & \multirow{3}{*}{$x^{2}=1.471 ; d f=2 ; p=0.479$} \\
\hline & No & 5 & 4.8 & 8 & 2.5 & \\
\hline & Not sure & 19 & 18.3 & 64 & 20.2 & \\
\hline \multicolumn{7}{|c|}{ STDs treatment } \\
\hline \multirow{2}{*}{ Gender } & Female & 2 & 12.5 & 222 & 54.8 & \multirow{2}{*}{$x^{2}=11.069 ; \mathrm{df}=1 ; \mathrm{p}=0.002$} \\
\hline & Male & 14 & 87.5 & 183 & 45.2 & \\
\hline \multirow{3}{*}{$\begin{array}{l}\text { Age group } \\
\text { (in years) }\end{array}$} & $19-20$ & 1 & 6.3 & 46 & 11.4 & \multirow{3}{*}{$x^{2}=1.986 ; \mathrm{df}=2 ; \mathrm{p}=0.371$} \\
\hline & $21-22$ & 3 & 18.8 & 127 & 31.4 & \\
\hline & $23-24$ & 12 & 75.0 & 232 & 57.3 & \\
\hline \multirow{3}{*}{$\begin{array}{l}\text { Religion allow } \\
\text { YFRHS }\end{array}$} & Yes & 8 & 50.0 & 317 & 78.3 & \multirow{3}{*}{$x^{2}=7.006 ; d f=2 ; p=0.030$} \\
\hline & No & 1 & 6.3 & 12 & 3.0 & \\
\hline & Not sure & 7 & 43.8 & 76 & 18.8 & \\
\hline \multicolumn{7}{|c|}{ General counselling } \\
\hline \multirow{2}{*}{ Gender } & Female & 153 & 53.5 & 71 & 52.6 & \multirow{2}{*}{$x^{2}=0.030 ; \mathrm{df}=1 ; \mathrm{p}=0.862$} \\
\hline & Male & 133 & 46.5 & 64 & 47.4 & \\
\hline \multirow{3}{*}{$\begin{array}{l}\text { Age group } \\
\text { (in years) }\end{array}$} & $19-20$ & 23 & 8.0 & 24 & 17.8 & \multirow{3}{*}{$x^{2}=9.821 ; d f=2 ; p=0.007$} \\
\hline & $21-22$ & 87 & 30.4 & 43 & 31.9 & \\
\hline & $23-24$ & 176 & 61.5 & 68 & 50.4 & \\
\hline \multirow{3}{*}{$\begin{array}{l}\text { Religion allow } \\
\text { YFRHS }\end{array}$} & Yes & 203 & 71.0 & 122 & 90.4 & \multirow{3}{*}{$x^{2}=10.803 ; \mathrm{df}=2 ; \mathrm{p}=0.024$} \\
\hline & No & 6 & 2.1 & 7 & 5.2 & \\
\hline & Not sure & 77 & 26.9 & 6 & 4.4 & \\
\hline
\end{tabular}

Table 4: Socio-economic factors and utilization of YFRH services.

\begin{tabular}{|c|c|c|c|c|c|c|}
\hline \multirow{2}{*}{ Characteristics } & & \multicolumn{2}{|c|}{ Utilized } & \multicolumn{2}{|c|}{ Not-utilized } & \multirow{2}{*}{ Statistic } \\
\hline & & $\mathbf{N}$ & $\%$ & $\mathbf{N}$ & $\%$ & \\
\hline \multicolumn{7}{|l|}{ VCT services } \\
\hline \multirow{2}{*}{ Had source of income } & Yes & 115 & 65.0 & 98 & 40.2 & \multirow{2}{*}{$\begin{array}{l}x^{2}=25.257 ; d f=1 ; \\
p=0.0001\end{array}$} \\
\hline & No & 62 & 35.0 & 146 & 59.8 & \\
\hline \multirow{2}{*}{$\begin{array}{l}\text { Guardian employment } \\
\text { status }\end{array}$} & Non-formal employment & 125 & 70.6 & 153 & 62.7 & \multirow{2}{*}{$\begin{array}{l}x^{2}=2.866 ; d f=1 \\
p=0.090\end{array}$} \\
\hline & Formal employment & 52 & 29.4 & 91 & 37.3 & \\
\hline \multicolumn{7}{|l|}{ ANC services } \\
\hline \multirow{2}{*}{ Had a source of income } & Yes & 46 & 86.8 & 167 & 45.4 & \multirow{2}{*}{$\begin{array}{l}x^{2}=31.785 ; \mathrm{df}=1 ; \\
p=0.0001\end{array}$} \\
\hline & No & 7 & 13.2 & 201 & 54.6 & \\
\hline \multirow{2}{*}{$\begin{array}{l}\text { Guardian employment } \\
\text { status }\end{array}$} & Non-formal employment & 41 & 77.4 & 237 & 64.4 & \multirow{2}{*}{$\begin{array}{l}x^{2}=3.467 ; d f=1 ; \\
p=0.063\end{array}$} \\
\hline & Formal employment & 12 & 22.6 & 131 & 35.6 & \\
\hline \multicolumn{7}{|l|}{ STDs treatment } \\
\hline \multirow{2}{*}{ Had a source of income } & Yes & 12 & 75.0 & 201 & 49.6 & \multirow{2}{*}{$\begin{array}{l}x^{2}=3.963 ; \mathrm{df}=1 \\
\mathrm{p}=0.046\end{array}$} \\
\hline & No & 4 & 25.0 & 204 & 50.4 & \\
\hline \multirow{2}{*}{$\begin{array}{l}\text { Guardian employment } \\
\text { status }\end{array}$} & Non-formal employment & 16 & 100.0 & 262 & 64.7 & \multirow{2}{*}{$\begin{array}{l}x^{2}=8.555 ; \mathrm{df}=1 \\
\mathrm{p}=0.003\end{array}$} \\
\hline & Formal employment & 0 & 0.0 & 143 & 35.3 & \\
\hline \multicolumn{7}{|l|}{ FP services } \\
\hline \multirow{2}{*}{ Had a source of income } & Yes & 81 & 77.9 & 132 & 41.6 & \multirow{2}{*}{$\begin{array}{l}\mathrm{x}^{2}=41.154 ; \mathrm{df}=1 ; \\
\mathrm{p}=0.0001\end{array}$} \\
\hline & No & 23 & 22.1 & 185 & 58.4 & \\
\hline \multirow{2}{*}{$\begin{array}{l}\text { Guardian employment } \\
\text { status }\end{array}$} & Non-formal employment & 79 & 76.0 & 199 & 62.8 & \multirow{2}{*}{$\begin{array}{l}x^{2}=6.070 ; \mathrm{df}=1 \\
\mathrm{p}=0.014\end{array}$} \\
\hline & Formal employment & 25 & 24.0 & 118 & 37.2 & \\
\hline
\end{tabular}




\begin{tabular}{|c|c|c|c|c|c|c|}
\hline \multirow{2}{*}{ Characteristics } & & \multicolumn{2}{|c|}{ Utilized } & \multicolumn{2}{|c|}{ Not-utilized } & \multirow{2}{*}{ Statistic } \\
\hline & & $\mathbf{N}$ & $\%$ & $\mathbf{N}$ & $\%$ & \\
\hline \multicolumn{7}{|l|}{ General counselling } \\
\hline \multirow{2}{*}{$\begin{array}{l}\text { Had a source of } \\
\text { income }\end{array}$} & Yes & 151 & 52.8 & 62 & 45.9 & \multirow{2}{*}{$\begin{array}{l}x^{2}=1.732 ; d f=1 \\
p=0.188\end{array}$} \\
\hline & No & 135 & 47.2 & 73 & 54.1 & \\
\hline \multirow{2}{*}{$\begin{array}{l}\text { Guardian employment } \\
\text { status }\end{array}$} & Non-formal employment & 181 & 63.3 & 97 & 71.9 & \multirow{2}{*}{$\begin{array}{l}x^{2}=3000 ; d f=1 ; \\
p=0.083\end{array}$} \\
\hline & Formal employment & 105 & 36.7 & 38 & 28.1 & \\
\hline
\end{tabular}

\section{Socio-economic factors and utilization of YFRHS}

The youth who had a source of income utilized VCT and ANC and this was significantly associated with YRHFS utilization $(p<0.001)$. Youths income status and parent's employment status were significantly associated with STDs treatment $\left(\chi^{2}=3.963, \mathrm{p}=0.046\right)$ and $\left(\chi^{2}=8.555\right.$, $\mathrm{p}=0.003)$ respectively. Likewise, Parent's employment status had a role in family planning utilization $\left(\chi^{2}=6.070\right.$, $\mathrm{p}=0.014$ ).

\section{DISCUSSION}

The study findings showed that gender was greatly associated with utilization of ANC services, FP services and STDs treatment while age of an individual was associated with VCT services, FP services and counselling as reproductive health services offered to the youth. Utilization for all the reproductive health services increased with chronological age. The older youth in age group of 23-24 years utilized all the YFRHS more than those who were younger. This finding is in agreement with a study by Mutai which reported low utilization of RHS among young people due to poor understanding of their changing bodies and insufficient awareness of risks associated with early sexual debut, STI/HIV and pregnancy and shyness. ${ }^{10}$ The findings also agree with KDHS which revealed an increased uptake of family planning services among older youth, 20-24 years as compared to 10-19-year olds. ${ }^{5}$ In this study, it was observed that youths with a source of income had higher utilization of all youth reproductive health services. Thus, greatly associated with VCT services, ANC services and FP services, however it was not associated with counselling services. The employment/ or occupation of the youth's parent showed no significant association to most of utilization of YFRHS. The employment status only showed significant association to treatment of Sexually Transmitted Infection and family planning services. This confirms the finding that there is a cost attached to treatment as was mentioned by some youth. This is in agreement with a study by Shikuku who found that in STI management, a lot of time involves laboratory investigations that are charged for irrespective of whether the individual is a school youth or not thus explaining the connection between employment status and this utilization. ${ }^{9}$ This means that without money the youth might not access and utilize the service. This finding is in agreement with a studies which showed that generally health service utilization including RHS was tied to economic aspects of an individual. ${ }^{8,11,12}$ This finding was also brought out when a big percentage of the youth said that they missed the services due to cost/fee charged on some services. The implication of this finding is that majority of the youth are likely not to seek medical care and treatment for these infections in time and this can lead to serious reproductive health complications such as infertility in future.

\section{CONCLUSION}

Older youth between 23-24 years utilized the services more than the younger youth owing to their increased knowledge of these services $p<0.05$ thereby rejecting hypothesis one that stated that there was no relationship between demographic factors and utilization of YFRHS. The study therefore concludes that the younger university youth aged between 19-20 years utilization of YFRHS is low and creating awareness of these services to them is important to enable increase their knowledge and understanding and in turn scale up their utilization. Parent's employment did not play a significant role in the utilization of all YFRHS except for treatment of STIs and FP services. University youths with a source of income had higher utilization of all youth reproductive health services. Thus, greatly associated with VCT services, ANC services and FP services, however it was not associated with counselling services. Therefore, there is a need to reach the younger youth with age appropriate YFRHS message to enlighten and help them make right decisions as some are already sexually active as reported that the adolescent get into sexual debut early and that many have had sex before university education.

\section{ACKNOWLEDGEMENTS}

Special gratitude goes to school of public health for guidance and support. Sincere gratitude to all university administration, Nairobi county director of health, students and healthcare workers who took part to make this study successful.

\section{Funding: No funding sources}

Conflict of interest: None declared

Ethical approval: The study was approved by the Mount Kenya University- Ethical Review Committee and a permission by National Commission for Science, Technology and Innovation, Kenya

\section{REFERENCES}

1. World Health Organization. Regional Office for South-East Asia. (2018). Strategic Guidance on Accelerating Actions for Adolescent Health in 
South-East Asia Region (2018-2022). World Health Organization. Available at: https://apps.who.int/iris/ handle/10665/274312.

2. Mazur A, Brindis CD, Decker MJ. Assessing youthfriendly sexual and reproductive health services: A systematic review. BMC Health Serv Res. 2018;18(1):1-12.

3. Sujindra E, Bupathy A. Adolescent friendly health services: perceptions and practice of medical professionals. Int J Reprod Contraception, Obstet Gynecol. 2016;5(9):2968-72.

4. Ministry of Health, Kenya. National Guidelines for Provision of Adolescent and Youth Friendly Services in Kenya. 4. Ministry of Health, Kenya. 2016.

5. Kenya National Bureau of Statistics and ICF Macro. Kenya Demographic and Health Survey 2014-2015. Calverton, Maryland; Kenya Nat Bur Stat. 2014;58(1):1-132.

6. Abate AT, Ayisa AA, W Mariam, Tesfamichael GM. Reproductive health services utilization and its associated factors among secondary school youths in Woreta town, South Gondar, North West Ethiopia: a cross sectional study. BMC Res Notes. 2019;12(1):90.

7. Sotolongo J, House LD, Swanson S, Davis SEH. Integrated community strategies for linking youth to adolescent reproductive health services: a case study. J Adolesc Health. 2017;60(3):S45-50.
8. Mbugua SM, Karonjo JM. Reproductive health knowledge among college students in Kenya. BMC Public Health. 2018;18(1):1-7.

9. Shikuku CK. Delivery of youth friendly services in kenya: towards a targeted approach. Public Policy Adminis Res. 2014;4(7):115-9.

10. Mutai KJ. An assessment of factors influencing utilization of youth- friendly reproductive health services in Waldai Ward, Belgut Sub-CountyKenya. Afr J Reprod Health. 2016;9(3):253-96.

11. Nmadu AG. Access and utilization of reproductive health services among adolescents in Kaduna North Local Government, Kaduna State, North-West, Nigeria. North-Eastern Hill Univ J. 2017;8(3):1-107.

12. James S, Pisa PT, Imrie J, Beery MP, Martin C, Skosana C, et al. Assessment of adolescent and youth friendly services in primary healthcare facilities in two provinces in South Africa. BMC Health Serv Res. 2018;18(1):809.

Cite this article as: Mutua FM, Karonjo J, Nyaberi JM, Kamau P, Kausya J, Mugai F. Sociodemographic and economic factors influencing utilization of youth friendly reproductive health services among youths in selected universities in Nairobi County, Kenya. Int J Community Med Public Health 2020;7:2437-42. 